Scientific Review Engineering and Environmental Sciences (2022), 31 (1), 3-13

Sci. Rev. Eng. Env. Sci. (2022), 31 (1)

https://srees.sggw.edu.pl

Mohamed Khatif Tawaf MOHAMED YUSOF ${ }^{1 凶}$ (D) https://orcid.org/0000-0001-6929-122X

Siti Shahidah SHARIPUDIN ${ }^{1}$ iD https://orcid.org/0000-0003-1278-3084

Shahrul Nizam MOHAMMAD ${ }^{1}$ iD https://orcid.org/0000-0002-5720-7964

Azmi ROSLAN ${ }^{2}$ iD https://orcid.org/0000-0002-8201-2923

Zeno MICHAEL ${ }^{3}$ iD https://orcid.org/0000-0002-3880-0148

Ilya Izyan SHAHRUL AZHAR ${ }^{3}$ iD https://orcid.org/0000-0002-3033-658X

Nurrul Amilin ZAINAL ABIDIN ${ }^{3}$ iD https://orcid.org/0000-0001-7376-478X

${ }^{1}$ Universiti Teknologi MARA, College of Engineering, School of Civil Engineering, Malaysia

${ }^{2}$ Universiti Teknologi MARA, College of Engineering, School of Chemical Engineering, Malaysia

${ }^{3}$ Universiti Teknologi MARA, College of Engineering, School of Mechanical Engineering, Malaysia

\title{
FEASIBILITY STUDY OF PALM OIL BOILER ASH (POBA) AS A PARTIAL REPLACEMENT OF SAND IN FOAMED CONCRETE
}

Key words: foamed concrete, palm oil boiler ash (POBA), sand replacement, compressive strength, water absorption

\section{Introduction}

Aside from integrating natural fiber materials into foamed concrete matrix, industrial by-products derived from agricultural crops are considered as feasible resources in the expansion of an environmentally friend- ly and sustainable concrete. Each unwanted waste produced due to agricultural activities has distinguished properties that make them suitable in proper application in concrete. The wastes include oil palm kernel shell (OPKS), coconut shell, fly ash (Rashad, 2016), rice husk ash (RHA), and oil palm shell (OPS) (Mannan \& Ganapathy, 2004). Those are referred to as additional cementitious materials due to their pozzolanic properties that improve the mechanical properties of solid concrete (Awang, Al-Mulali, Khalil 
\& Aljoumaily, 2014). On the other hand, the integration of industrial by-products in the foamed cellular concrete structure matrix also can aid in the establishment of the number of pores, thus creating a lighter product. By combining the effects of pozzolanic activity and pores generation in foamed concrete matrix, it will improve thermal conductivity, lightweightedness of foamed concrete, and compressive strength of foamed concrete. Malaysia is one of the world's largest producers of palm oil, where the industry generates large quantities of solid waste such as palm oil boiler ash (POBA). These oil palm wastes have contributed to a major disposal problem to the society and environment. On the other hand, global demand for concrete is expected to keep increasing and the price of concrete materials are escalating due to limited resources of cement, such as fine aggregate and coarse aggregate.

The scenario is a good opportunity to utilise POBA to be blended with foamed concrete as an alternative to the conventional high priced concrete materials. The utilisation of POBA in foamed concrete has a huge potential to reduce the weight of concrete with acceptable strength instead of being disposed of as waste materials. A few researches have been carried out to resolve the shortage of natural sand and the upsurge in the waste's disposal problems (Flores-Johnson \& Li, 2012; Sankh, Biradar, Naghathan \& Ishwargol, 2014; Payá et al., 2017; Castillo-Lara et al., 2020; Tran \& Ghosh, 2020). By utilising those waste into the concrete blends creates opportunity in solving environmental issues. For instance, utilising oil palm shell (OPS), coconut shell, and oil palm kernel shell (OPKS) as aggregates in concrete (Awang et al., 2014; Muthusamy, Zamri, Zubir, Kushbiantoro \& Ahmad, 2015) or using rice husk ash and palm oil fuel ash (POFA) as cement replacement material (Lim, Tan, Lim \& Lee, 2013), however only a few use the wastes as sand replacement in producing concrete. In 2014, there are studies where the properties of foamed concrete replaced by the semi-processed oil palm ash or POFA (Awang et al., 2014) and another study (Muthusamy et al., 2015) using POFA as cement replacement in the application of lightweight concrete. More study on $20 \%$ of POFA as cement replacement has been conducted in 2010 with different fineness where it was concluded that $20 \%$ of POFA as cement replacement but different fineness has improved the strength of POFA concrete towards the acidic corrosion (Budiea, Hussin, Muthusamy \& Ismail, 2010). POFA, if treated, will enhance the mechanical and physical properties of the concrete at initial phases, which has been proven by a recent study (Alsubari, Shafigh, Ibrahim \& Jumaat, 2018).

Also, it is reported that replacing the sand with coarse fly ash as filler in the foamed concrete showed a spread value 2.5 times higher than that of cement-sand mix (Jones \& McCarthy, 2005b; Lim et al., 2013). If POBA can be used as sand replacement in concrete for structural applications, it would be favourable to the environment by turning these materials into an appropriate product. In addition, this concrete can be employed for construction of low-cost houses, particularly in the locality of oil palm plantations. However, the flexural behaviour and compressive strength of POBA as sand replacement in lightweight concrete must be further examined and clearly established for future development. Therefore, the objective of this study are to evaluate the feasibility of POBA as partial replacement material in foamed concrete and to determine the optimum composition of POBA to be used as sand replacement. The suitability of foamed concrete with POBA blends for conventional 
Mohamed Yusof, M. K. T., Sharipudin, S. S., Mohammad S. N., Roslan, A., Michael, Z., Shahrul Azhar, I. I., Zainal Abidin, N. A. (2022). Feasibility study of palm oil boiler ash (POBA) as a partial replacement of sand in foamed concrete. Sci. Rev. Eng. Env. Sci., 31 (1), 3-13.

concrete replacement will be determined with several tests that are being conducted which are water absorption test, density test, and compression strength test.

\section{Methodology}

\section{Materials and sample preparation}

The materials used in the laboratory to cast foamed concrete consist of original Portland cement according to the standard

a

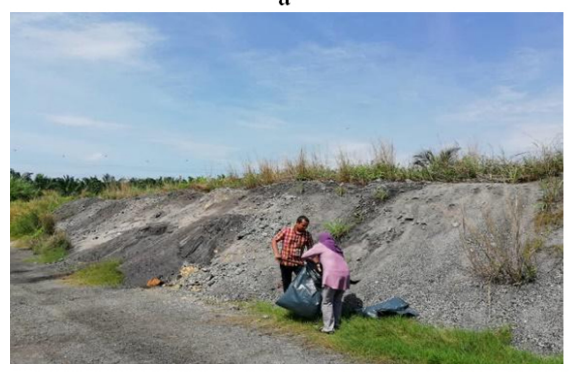

$\mathrm{c}$

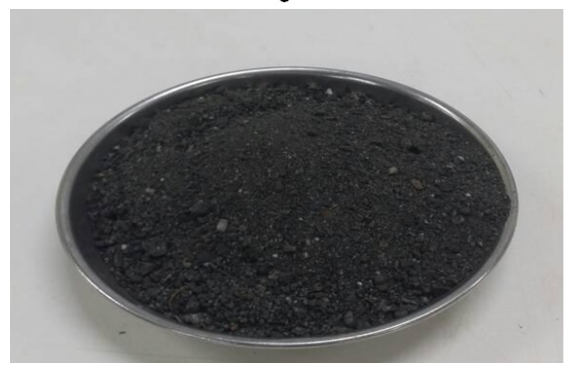

e

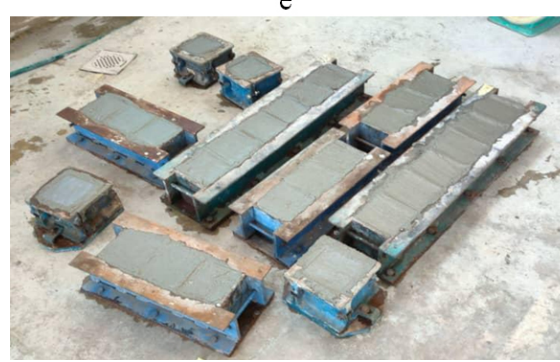

BS EN 197-2000 (British Standards Institution [BSI], 2000), foaming agent, POBA, free water, and fine aggregate. POBA was collected from the Palm Oil Factory at Telok Sengat Palm Oil Mill, Kota Tinggi Johor as shown in Figure 1a and Figure 1b. The POBA was then sieved through a single size that is passing $2 \mathrm{~mm}$ sieve size to be used to replace sand. Preformed foamed concrete was made by using synthetic-based foaming agents. A foamed concrete with a $1,400 \mathrm{~kg} \cdot \mathrm{m}^{-3}$ density was designed in this study. The sand was replaced with POBA with various
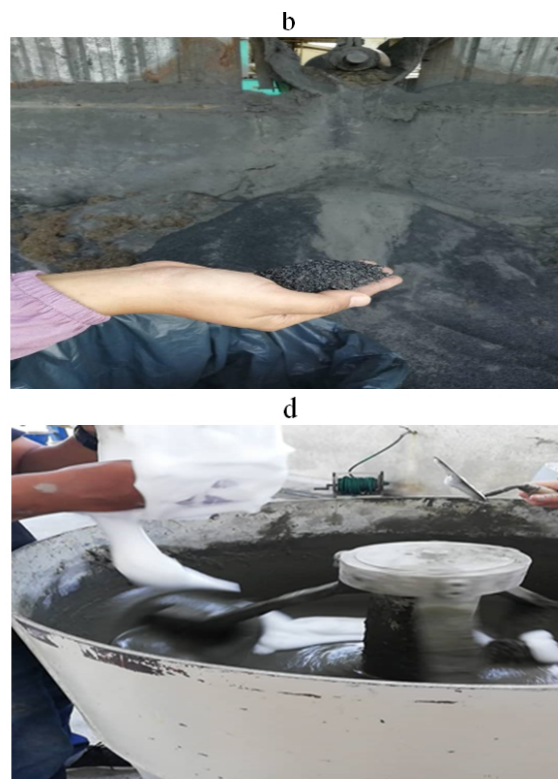

f

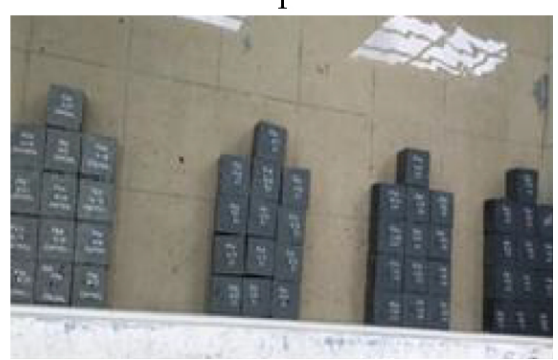

FIGURE 1. Foamed concrete casting process: $a, b$ - collection of POBA sample from Palm Oil Factory at Telok Sengat Palm Oil Mill; c - POBA sample passing $2 \mathrm{~mm}$ sieve; $\mathrm{d}$ - POBA-foamed concrete mix; $\mathrm{e}$ - cast into the mould; $\mathrm{f}$ - curing the foamed concrete sample 
percentages of mass replacement such as $0,4,8$ and $12 \%$ concerning designed density in this study. Detail of mix proportions of samples is shown in Table 1. All mixes were kept at 1.0 and 0.6 respectively for the ratios of the sand-cement $(\mathrm{S} / \mathrm{C})$ and water-cement/binder ratios. In this study, foamed concrete specimens with dimensions of $100 \times 100 \times 100$ $\mathrm{mm}$ were prepared. The samples were water curing in the water tank at 7, 28, 60 and 90 days. All processes are shown in Figure 1. Table 1 summarises the details of the mixed proportions of samples employed. Foamed concrete was prepared within four main steps, including the preparation of the mortar mix, foam preparation, foamed concrete production, and lastly density of the foamed concrete determination. Figure 1c to Figure 1e show the foamed concrete casting process conducted in this study. The density of the mixture was identified prior to the inclusion of the foam. Plastic density was set at about $\pm 50 \mathrm{~kg} \cdot \mathrm{m}^{-3}$ of the target density, which corresponds to the tolerance that is used in industry for the production of foamed concrete (Jones \& McCarthy, 2005a, 2005b, 2006; Kearsley \& Mostert, 2015). The additional foam was prepared as needed until the design density of the foamed concrete was achieved. The samples of the foamed concrete were cast based on guidelines in BS EN 12350$-1: 2009$ (BSI, 2009). Portafoam was used as the foaming machine in this study to generate the foam from the foaming agent to be mixed with the concrete.

\section{Test method}

\section{Water absorption test}

Water-resistance in concrete is usually measured using water absorption tests. This test was performed in accordance with the standard BS 1881-122:2011 (BSI, 2011), which measures the water amount that penetrates the concrete samples while submerged. The positive result indicated by the lower absorption value of the concrete sample. The crystals inside the crystalline admixtures such as foamed concrete, grow continuously over time, which may affect the result of the water absorption test. Therefore, for more realistic and reliable results, the sample of the foamed concrete was tested at later ages (56 or 90 days) for its water absorption properties. Three samples of foamed concrete for each POBA mix proportion will be tested at the age of 90 days. The samples were placed in the drying oven for $72 \mathrm{~h}$, as shown in Figure $2 \mathrm{a}$. Then, the samples were weighed and recorded. The samples were submerged instantly in a water tank at a depth such that there was $25 \pm 5 \mathrm{~mm}$ of water over the top of the specimen and in the position of its longitudinal axis in the horizontal as shown in Figure 2b. The sample was submerged in the water tank for a period of $30 \pm 0.5 \mathrm{~min}$. After that, the sample was removed from the tank and the bulk of water on the sample surface was removed by shaking the sample. Then the samples were dried up from the free water as rapidly as possible using a dry

TABLE 1. Detail of mix proportions of samples

\begin{tabular}{|l|c|c|c|c|c|}
\hline \multirow{2}{*}{ Mixture sample } & \multicolumn{4}{|c|}{ Mix proportion $\left[\mathrm{kg} \cdot \mathrm{m}^{-3}\right]$} & $\begin{array}{c}\text { Foaming agent } \\
{\left[1 \cdot \mathrm{m}^{-3}\right]}\end{array}$ \\
\cline { 2 - 6 } & cement & fine aggregate & POBA & water & 301.55 \\
\hline Control & 538 & 538 & - & 323 & 301.55 \\
\hline 4 POBA & 538 & 517 & 21 & 323 & 301.55 \\
\hline 8 POBA & 538 & 495 & 43 & 323 & 301.55 \\
\hline 12 POBA & 538 & 473 & 65 & 323 & \\
\hline
\end{tabular}


Mohamed Yusof, M. K. T., Sharipudin, S. S., Mohammad S. N., Roslan, A., Michael, Z., Shahrul Azhar, I. I., Zainal Abidin, N. A. (2022). Feasibility study of palm oil boiler ash (POBA) as a partial replacement of sand in foamed concrete. Sci. Rev. Eng. Env. Sci., 31 (1), 3-13.

a

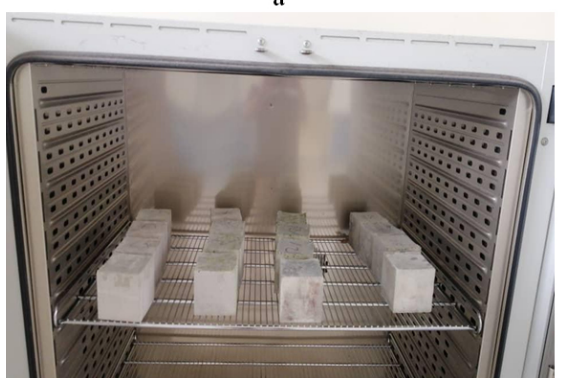

b

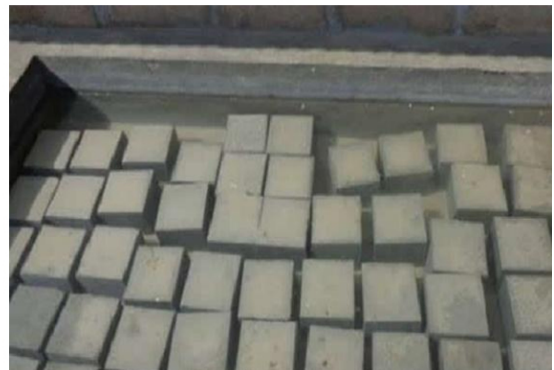

FIGURE 2. Water absorption test process: $\mathrm{a}$ - dry-oven the sample for $72 \mathrm{~h} ; \mathrm{b}$ - sample immersed in the water tank

cloth. Finally, the weight of the samples are recorded, and the percentage of water absorbed was calculated.

\section{Uniaxial compressive strength}

The compressive strength test was conducted using three samples of foamed concrete for each POBA mix proportion at the ages of 7, 28, 60 and 90 days. This test was conducted to assess the strength development of the samples with the different mix proportions of POBA, as shown in Figure 3. The size of the foamed concrete samples used in the test was $100 \times 100 \times 100 \mathrm{~mm}$, following the standard BS EN 12390-3:2009 (BSI, 2009). Compression testing machine (CTM) was used in this test and the foamed concrete sample was positioned so that the load was applied in the opposing direction to the samples. The sample was carefully aligned and load was applied until the sample breaks. The compressive strength of a specimen was determined and recorded.

\section{Density determination}

Foamed concrete with a density of $1,400 \mathrm{~kg} \cdot \mathrm{m}^{-3}$ was prepared in this research. The density of foamed concrete was determined after the foamed was added to the mixture. The mixture of foamed concrete was poured into a mould and then weighed to get the wet density of the mixture. If the density was higher than $1,400 \mathrm{~kg} \cdot \mathrm{m}^{-3}$, it means that the amount of foamed was not a

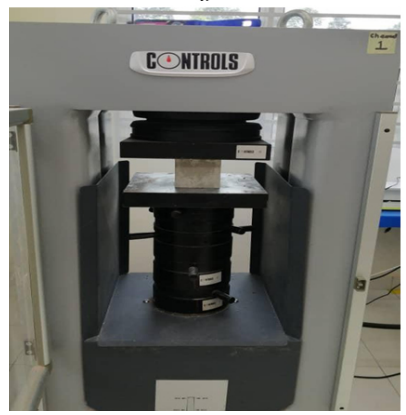

b

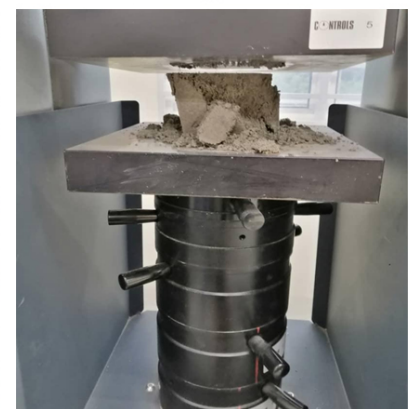

$\mathrm{c}$

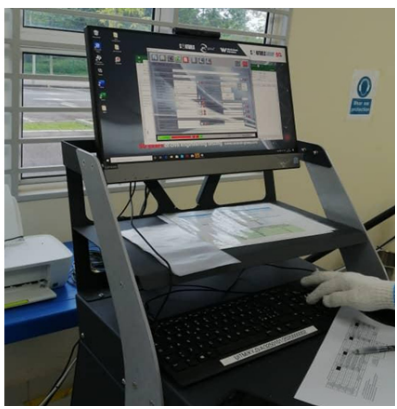

FIGURE 3. Uniaxial compressive strength process: $a$ - sample placed in position; $b$ - load applied until failure; $\mathrm{c}$ - maximum load at failed 
yet sufficient in the mixture and additional foam was added before it was mixed again in the concrete mixer. Then, the mixture was poured into the mould and weighed again until the desired density was achieved. After the curing process, the foamed concrete was left to dry before the weight was determined once more. Based on the weight reading, the dry density of foamed concrete was determined.

\section{Result and discussion}

\section{Density of the sample}

Figure 4 shows the density of foamed concrete with $0,4,8$ and $12 \%$ of POBA replacement of fine aggregate for the curing age of 7, 28, 60 and 90 days. The density are recorded lowest for foamed concrete without POBA as fine aggregate replacement, which are 1,294.7, 1,306.8, 1,358.2 and $1,362.1 \mathrm{~kg} \cdot \mathrm{m}^{-3}$ at 7, 28, 60 and 90 days of curing age respectively. Meanwhile, the density for foamed concrete with $12 \%$ of POBA as fine aggregate replacement recorded the highest values with $1,446.5$, $1,541.0,1,552.0$ and $1,604.3 \mathrm{~kg} \cdot \mathrm{m}^{-3}$ at the similar curing days. Additionally, the value of density for foamed concrete with $4 \%$ of POBA are 1,323.3, 1,345.6, 1,399.0 and $1,389.1 \mathrm{~kg} \cdot \mathrm{m}^{-3}$, meanwhile for foamed concrete with $8 \%$ of POBA the recorded density are 1,387.0, 1,435.5, 1,448.4 and $1,454.3 \mathrm{~kg} \cdot \mathrm{m}^{-3}$ for the curing age of 7,28 , 60 and 90 days respectively.

In this research, it was found that the greater percentage of POBA as replacement of fine aggregate lead to a higher value of dry density of the foamed concrete. It is because the amount of foam added in the foamed concrete is lesser for the higher percentage of POBA in foamed concrete as the density of fine aggregate is greater than POBA. Therefore, mixture with higher percentage of POBA will be added with less amount of foam so that the value of wet density of foamed concrete fixed to $1,400 \mathrm{~kg} \cdot \mathrm{m}^{-3}$. Thus, the sample with higher percentage of POBA will be added with less amount of foam, which dries out and create less voids in the foamed concrete during curing process. On the other hand, this research found that the value of density of foamed concrete rises with the increase of curing days. The trend shows that longer curing days will result in the higher value of density for most samples of foamed concrete.

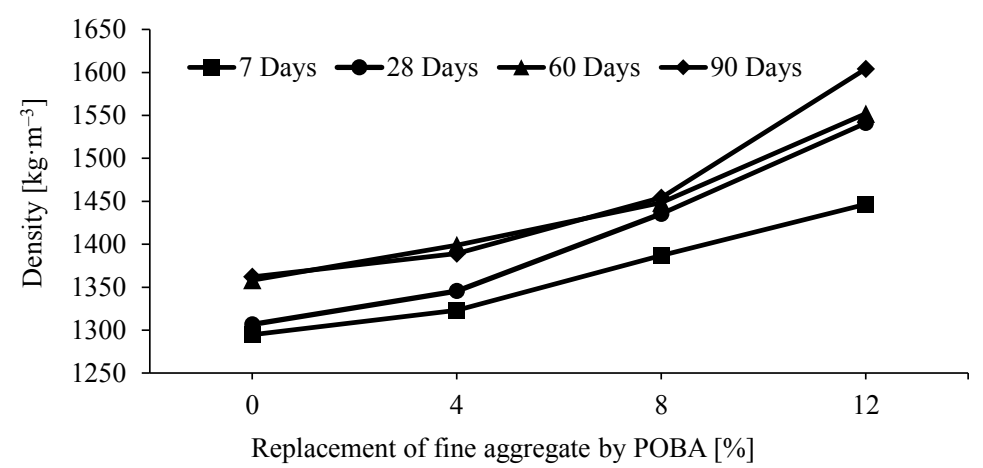

FIGURE 4. Density of the foamed concrete sample 
Mohamed Yusof, M. K. T., Sharipudin, S. S., Mohammad S. N., Roslan, A., Michael, Z., Shahrul Azhar, I. I., Zainal Abidin, N. A. (2022). Feasibility study of palm oil boiler ash (POBA) as a partial replacement of sand in foamed concrete. Sci. Rev. Eng. Env. Sci., 31 (1), 3-13.

This indicates that the uniformity of foamed concrete enhanced with the increase of curing days. As a result, the dry density of foamed concrete increase with the increase of curing days. This finding is true according to previous research that has been conducted that found water loss from concrete decreases with increasing curing days (Memon, Sam, Awang \& Memon, 2018).

\section{Water absorption test}

Table 2 shows the percentage of water absorption by various percentages of POBA. The result found that the foamed concrete with $12 \%$ POBA as the sand replacement showed the highest percentage of water absorption (10.4\%), while the control sample showed the lowest value.

The trend on the water absorption shown in Figure 5 indicates that the increasing amount of POBA in the foamed concrete will increase the water absorption value in the foamed concrete sample. Standard con- crete has a mean water absorption value within a range of $3-4 \%$ and this value is expected to be much higher in foamed concrete due to the higher number of voids or porosity values in foamed concrete (Brady, Watts \& Jones, 2001). The average value of water absorption for all the samples that contain POBA is $9.5 \%$ and the replacement of POBA as partial replacement of sand in foamed concrete showed an overall $28 \%$ of increment of water absorption value. This higher amount of porosity in foamed concrete depends on the concentration of the foaming agent that is being used and also the mix design proportion where its density plays an important role which has a major influence on the physical and mechanical properties of the sample such as water absorption value and compression strength.

Moreover, POBA loses some of its element during the hydration process and is diluted in water as an ion. The hydration reaction consumes these ions, forming ettringite and calcium silicate hydrate (C-S-H).

TABLE 2. Water absorption value for foamed concrete sample

\begin{tabular}{|c|c|c|c|c|c|c|}
\hline \multirow{2}{*}{ Concrete sample } & \multirow{2}{*}{ Criteria } & \multicolumn{4}{|c|}{ Sample number } & \multirow{2}{*}{ AVG } \\
\hline & & 1 & 2 & 3 & 4 & \\
\hline \multirow{3}{*}{ Control } & dry weight $[\mathrm{kg}]$ & 1110.3 & 1111.1 & 1139.5 & 1150.5 & 1127.9 \\
\hline & saturated weight $[\mathrm{kg}]$ & 1200.8 & 1199.3 & 1233.0 & 1239.2 & 1218.1 \\
\hline & $\%$ of water absorbed & 7.5 & 7.4 & 7.6 & 7.2 & 7.4 \\
\hline \multirow{3}{*}{$4 \%$} & dry weight [kg] & 1105.8 & 1103.5 & 1095.1 & 1117.1 & 1105.4 \\
\hline & saturated weight $[\mathrm{kg}]$ & 1189.1 & 1196.5 & 1178.9 & 1206.5 & 1192.8 \\
\hline & $\%$ of water absorbed & 7.5 & 8.4 & 7.7 & 8.0 & 7.9 \\
\hline \multirow{3}{*}{$8 \%$} & dry weight $[\mathrm{kg}]$ & 1167.4 & 1186.2 & 1187.0 & 1185.6 & 1181.6 \\
\hline & saturated weight $[\mathrm{kg}]$ & 1278.2 & 1311.9 & 1306.3 & 1309.8 & 1301.6 \\
\hline & $\%$ of water absorbed & 9.5 & 10.6 & 10.1 & 10.5 & 10.2 \\
\hline \multirow{3}{*}{$12 \%$} & dry weight [kg] & 1250.5 & 1253.5 & 1213.3 & 1257.9 & 1243.8 \\
\hline & saturated weight $[\mathrm{kg}]$ & 1372.2 & 1386.7 & 1343.4 & 1390.1 & 1373.1 \\
\hline & $\%$ of water absorbed & 9.7 & 10.6 & 10.7 & 10.5 & 10.4 \\
\hline
\end{tabular}




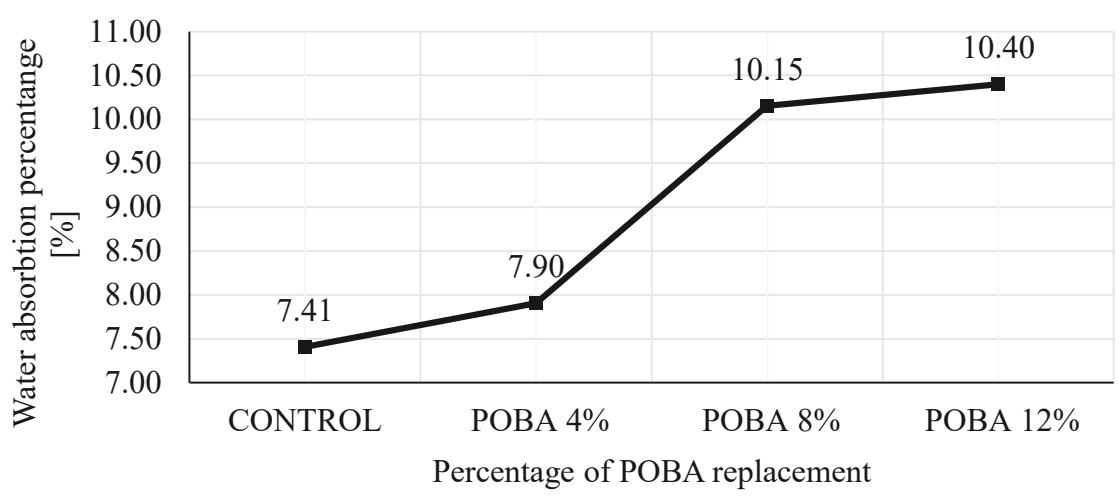

FIGURE 5. POBA and water absorption relationship

As a result, the size of POBA will reduce and has a greater tendency to leave void space during that dilution, which increases porosity in foam concrete that enhances the water absorption process.

\section{Compressive strength}

The compressive strength of foamed concrete mixes for all proportions of POBA is presented in Table 3. Besides that, Figure 6 shows the graphical compressive strength of all concrete in relation to the 4,8 and $12 \%$ of POBA amounts. Based on the data obtained, it appears that replacing sand with palm oil boiler ash improves the strength of foamed concrete significantly. POBA foamed concrete has a higher compressive strength than the control mixture, as indicated in Table 3 and Figure 6. The compressive strength consistently increased in the range of $4.34-13.50 \mathrm{~N} \cdot \mathrm{mm}^{-2}$, when the varied amounts of POBA were increased up to $12 \%$ at all curing periods. It can also be noticed that POBA foamed concrete for all replacement levels also develops strength at a slower rate at 7 days, with values ranging from 4.34 to $5.87 \mathrm{~N} \cdot \mathrm{mm}^{-2}$. According to Figure 6, it shows the strength of those concretes at 90 days increased dramatically, ranging from 5.20 to $13.50 \mathrm{~N} \cdot \mathrm{mm}^{-2}$. As a result of this finding, the POBA did have a role in the later development of strength. This is in agreement with the study conducted by Abdul Munir et al. (2015). Those authors mentioned that the rate of increase in strength of foamed concrete containing palm oil fuel ash (POFA) is slower than that of the normal concrete due to the use of POFA can slow the early hardening process. Additionally, Figure 6 reveals

TABLE 3. Compressive strength results of the foamed concrete mixes

\begin{tabular}{|l|c|c|c|c|}
\hline \multirow{2}{*}{ Concrete mix } & \multicolumn{4}{|c|}{ Compressive strength after curing time $\left[\mathrm{N} \cdot \mathrm{mm}^{-2}\right]$} \\
\cline { 2 - 5 } & 7 days & 28 days & 60 days & 90 days \\
\hline Control & 4.23 & 4.40 & 5.39 & 4.70 \\
\hline $4 \%$ POBA & 4.34 & 4.70 & 5.87 & 5.20 \\
\hline $8 \%$ POBA & 4.81 & 6.40 & 7.89 & 8.60 \\
\hline $12 \%$ POBA & 5.87 & 9.80 & 10.51 & 13.50 \\
\hline
\end{tabular}




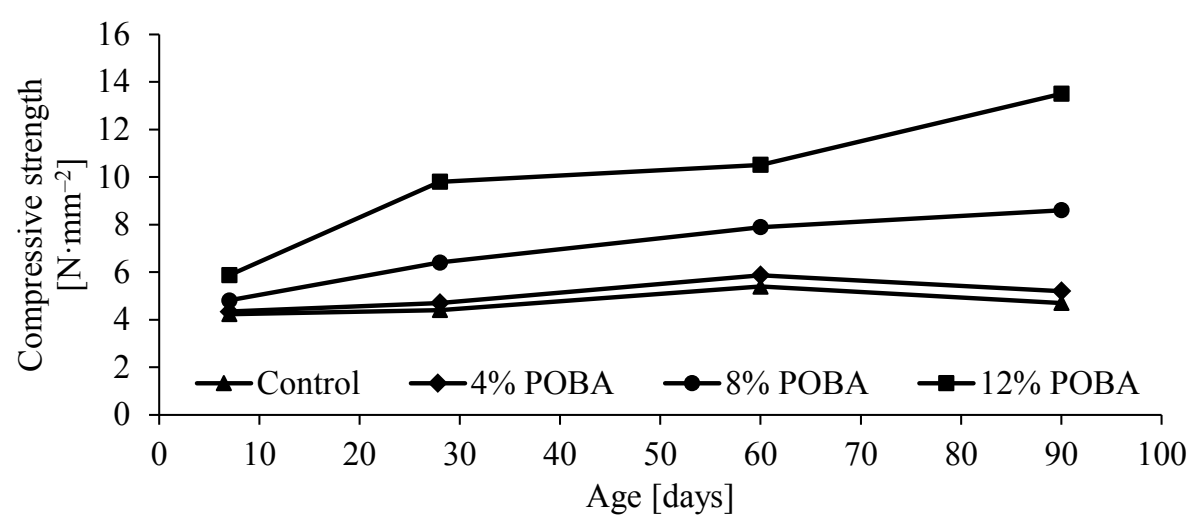

FIGURE 6. POBA and compressive strength relationship

that when POBA content was substituted at $12 \%$, the compressive strength achieved was higher than the other specimens, with values of $5.87,9.80,10.51$ and $13.50 \mathrm{~N} \cdot \mathrm{mm}^{-2}$ at 7 , 28,60 and 90 days respectively.

As a result, it obtains the maximum strength gain compared to the control mixture. This finding is achievable because $\mathrm{C}-\mathrm{S}-\mathrm{H}$ gels in the POBA produces bonding between aggregates and cement, resulting in increased concrete strength (Yee, 2017). At the same time, the fine particles in POBA are useful as a filler to fill voids in concrete (Yuan, 2012). Thus, the density of the concrete would be increased, which would aid in the development of strength. It's worth noting that foamed concrete can withstand larger levels of POBA without sacrificing strength.

\section{Conclusions}

The present study on utilising palm boiler ash (POBA) as sand replacement in concrete blends shows a promising result in lightweight foamed concrete development. Compression and water absorption tests were carried out on foamed concrete and POBA foamed con- crete as sand replacement at 4,8 and $12 \%$ of mass fractions with dry density of foamed concrete at $1,400 \mathrm{~kg} \cdot \mathrm{m}^{-3}$. The conclusions that can be deduced from this study:

- The inclusion of POBA has found to increase the compressive strength of the concrete blends, which was associated to the bonding between the aggregates and cement. The void in the concrete is filled with the fine particle of POBA which acts as filler and thus contributes to the compressive strength of the concrete. This can be seen from the results obtained, that among the three percent of replacement, $12 \%$ of POBA as sand replacement has been found to attribute the highest compressive strength.

- POBA percentage has showed a proportionally relationship to the dry density of foamed concrete mixture. The density of the foamed concrete with $12 \%$ of POBA resulted in the highest values of all percentages of POBA replacement. The integration of POBA in the foamed cellular concrete structure matrix has been found to aid in the establishment of the number of pores, thus creating a lightweight product with higher compressive strength. 
The use of POBA in lightweight concrete would be qualified to reduce the amount of solid waste disposed by the palm oil industry to the environment. From this study, it is feasible to use POBA as a supplementary cementing material, however, further research on the effect of different POBA particle sizes to the compressive strength of the concrete mixture and the stability of concrete to the temperature treatment should be conducted for future research and development.

\section{Acknowledgements}

This work was supported by the Bestari Research Grant Scheme Phase 2/2020 [600-UiTMCJ (PJIA.5/2)] awarded by the UiTM Cawangan Johor, Kampus Pasir Gudang, 81750 Masai, Johor.

\section{References}

Alsubari, B., Shafigh, P., Ibrahim, Z. \& Jumaat, M. Z. (2018). Heat-treated palm oil fuel ash as an effective supplementary cementitious material originating from agriculture waste. Construction and Building Materials, 167, 44-54. https://doi.org/10.1016/j.conbuildmat. 2018.01.134

Awang, H., Al-Mulali, M. Z., Khalil, H.A. \& Aljoumaily, Z. S. (2014). Utilisation of oil palm ash in foamed concrete. MATEC Web of Conferences, 15, 2-7. https://doi. org/10.1051/matecconf/20141501033

British Standards Institution [BSI] (2000). Cement. Composition, specifications and conformity criteria for common cements (BS EN 197-2000). London: British Standards Institution.

British Standards Institution [BSI] (2009). Testing hardened concrete. Compressive strength of test specimens (BS EN 12390-3:2009). London: British Standards Institution.
British Standards Institution [BSI] (2011). Testing concrete. Method for determination of water absorption (BS 1881-122:2011). London: British Standards Institution.

Brady, K. C., Watts, G. R. A. \& Jones, M. R. (2001). Specification for foamed concrete. Crowntrone, UK: TRL Ltd.

Budiea, A., Hussin, M., Muthusamy, K. \& Ismail, M. (2010). Performance of High Strength POFA Concrete in Acidic Environment. Concrete Research Letters, 1 (1), 14-18.

Castillo-Lara, J. F., Flores-Johnson, E. A., Valadez-Gonzalez, A., Herrera-Franco, P. J., Carrillo, J. G., Gonzalez-Chi, P. I. \& Li, Q. M. (2020). Mechanical properties of natural fiber reinforced foamed concrete. Materials, 13 (14), 3060. https://doi.org/10.3390/ ma13143060

Flores-Johnson, E. A. \& Li, Q. M. (2012). Structural behaviour of composite sandwich panels with plain and fibre-reinforced foamed concrete cores and corrugated steel faces. Composite Structures, 94 (5), 1555-1563. https:// doi.org/10.1016/j.compstruct.2011.12.017

Jones, M. R. \& McCarthy, A. (2005a). Preliminary views on the potential of foamed concrete as a structural material. Magazine of Concrete Research, 57 (1), 21-31. https:// doi.org/10.1680/macr.2005.57.1.21

Jones, M. R. \& McCarthy, A. (2005b). Utilising unprocessed low-lime coal fly ash in foamed concrete. Fuel, 84 (11), 1398-1409. https:// doi.org/10.1016/j.fuel.2004.09.030

Jones, M. R. \& McCarthy, A. (2006). Heat of hydration in foamed concrete: Effect of mix constituents and plastic density. Cement and Concrete Research,36 (6), 1032-1041.https:// doi.org/10.1016/j.cemconres.2006.01.011

Kearsley, E. P. \& Mostert, H. F. (2015). Designing mix composition of foamed concrete with high fly ash contents. In: R.K. Dhir, M.D. Newlands \& A. McCarthy (Eds.), Use of Foamed Concrete in Construction: Proceedings of the International Conference held at the University of Dundee, Scotland, UK on 5 July 2005 (pp. 29-36). London: Thomas Telford Publishing.

Lim, S. K., Tan, C. S., Lim, O. Y. \& Lee, Y. L. (2013). Fresh and hardened properties of lightweight foamed concrete with palm oil 
fuel ash as filler. Construction and Building Materials, 46, 39-47. https://doi.org/10.1016/ j.conbuildmat.2013.04.015

Mannan, M. A. \& Ganapathy, C. (2004). Concrete from an agricultural waste-oil palm shell (OPS). Building and Environment, 39 (4), 441-448. https://doi.org/10.1016/ j.buildenv.2003.10.007

Memon, R. P., Sam, A. R. M., Awang, A. Z. \& Memon, U. I. (2018). Effect of Improper Curing on the Properties of Normal Strength Concrete. Engineering, Technology \&amp; Applied Science Research, 8 (6), 3536-3540. https://doi.org/10.48084/etasr.2376

Munir, A., Abdullah, Huzaim, Sofyan, Irfandi \& Safwan (2015). Utilization of palm oil fuel ash (POFA) in producing lightweight foamed concrete for non-structural building material. Procedia Engineering, 125 (December), 739-746. https://doi.org/10.1016/ j.proeng.2015.11.119

Muthusamy, K., Zamri, N., Zubir, M. A., Kusbiantoro, A. \& Ahmad, S. W. (2015). Effect of Mixing Ingredient on Compressive Strength of Oil Palm Shell Lightweight Aggregate Concrete Containing Palm Oil Fuel Ash. Procedia Engineering, 125, 804-810. https://doi. org/10.1016/j.proeng.2015.11.142

Payá, J., Monzó, J., Borrachero, M. V., Soriano, L., Akasaki, J. L. \& Tashima, M. M. (2017). New inorganic binders containing ashes from agricultural wastes. In: H. Savastano Jr, J. Fiorelli \& S. Francisco dos Santos (Eds.), Sustainable and Nonconventional Construction Materials Using Inorganic Bonded Fiber Composites (pp. 127-164). Sawston: Woodhead Publishing. https://doi.org/10.1016/ B978-0-08-102001-2.00006-1

Rashad, A. (2016). Cementitious materials and agricultural wastes as natural fine aggregate replacement in conventional mortar and concrete. Journal of Building Engineering, 5, 119-141. https://doi.org/10.1016/ j.jobe.2015.11.011

Sankh, A. C., Biradar, P. M., Naghathan, S. J. \& Ishwargol, M. B. (2014). Recent trends in replacement of natural sand with different alternatives. IOSR Journal of Mechanical and Civil Engineering, 1, 59-66.
Tran, Q. \& Ghosh, P. (2020). Influence of pumice on mechanical properties and durability of high performance concrete. Construction and Building Materials, 249, 118741. https://doi. org/10.1016/j.conbuildmat.2020.118741

Yee, S. Y. (2017). Optimum replacement ratio of reincinerated palm oil fuel ash (Repofa) mortar without sacrifice its properties. Kampar: Faculty of Engineering and Green Technology. Retrieved from http://eprints.utar.edu. $\mathrm{my} / 2586$

Yuan, L. O. (2012). Engineering properties of lightweight foamed concrete incorporated with Palm Oil Fuel Ash (POFA). Universiti Tunku Abdul Rahman, Kampar [BEng project report]. Retrieved from http://eprints. utar.edu.my/id/eprint/509

\section{Summary}

Feasibility study of palm oil boiler ash (POBA) as a partial replacement of sand in foamed concrete. A study was conducted to explore the effect of palm oil boiler ash (POBA) on foamed concrete by varying the percentage of POBA over sand quantities $(0$, 4, 8 and $12 \%$ ). This paper primarily discusses the water absorption test, uniaxial compressive strength, and dry density findings. It indicates that substituting sand with POBA greatly enhances the strength of foamed concrete. When the quantity of POBA was raised up to $12 \%$ throughout all curing times, the compressive strength steadily increased in the range of $4.34-13.50 \mathrm{~N} \cdot \mathrm{mm}^{-2}$. Furthermore, the dry density of foamed concrete was shown to be directly related to the fraction of POBA in the mixture. The dry density of foamed concrete increases as the amount of POBA increases. Despite this, water absorption shown that increasing POBA increases water absorption percentage in foamed concrete from 7.4 to $10.4 \%$. This is due to the fact that a composition with a high POBA percentage will generate more pores than a mixture with a low POBA percentage. 